\title{
Effects of Paclobutrazol and Pinching on Ornamental Pepper
}

\author{
Songul Sever Mutlu ${ }^{1}$ and Ece Agan
}

AdDitional INDEX wORDs. Capsicum annuum, floriculture, plant growth regulators, $\mathrm{H} / \mathrm{D}$ ratio, anti-gibberellin

Summary. Pinching, manual removal of shoot apices, and/or plant growth regulators (PGRs) are used to create commercially preferred compact and wellbranched ornamental plants. The influence of paclobutrazol (PB) with and without pinching on the growth and fruit characteristics of a tall ornamental pepper (Capsicum annuиm) was assessed 2, 4, 6, and 8 weeks after the initial treatment. PB was sprayed on pinched or nonpinched whole plants at 5,10 , or $15 \mathrm{ppm}$ a.i. Pinching and $\mathrm{PB}$ reduced the plant height between $25 \%$ and $50 \%$ and the canopy diameter up to $8 \%$ and $17 \%$, respectively. Height/diameter ratio $(\mathrm{H} / \mathrm{D})$ ranged from 1.0 for 10 and 15 ppm PB applied to pinched plants to 2.3 for control plants. Paclobutrazol increased the SPAD chlorophyll value and total fruit number, delayed fruit set, and decreased fruit diameter and dry weight. The relationship between PB and plant height and diameter, SPAD chlorophyll value, dry weight, and fruit number was best explained by a third-order polynomial $\left(r^{2}=0.83-0.99\right)$. Paclobutrazol may substitute costly pinching treatment for height control and may offer an economic advantage for commercial greenhouse operators.

$\mathrm{P}$

eppers (Capsicum sp.) are well recognized as vegetable, spice, and ornamental crops (Rubatzky and Yamaguchi, 1997). Pepper plants bearing small, brightly colored fruit with dense foliage can make decorative displays indoors and outdoors. Ornamental peppers range in size and shape from short, compact plants with piquin-sized fruit to plants as tall as $1 \mathrm{~m}$ with full-sized fruit (Stommel and Bosland, 2006). However, for commercial purposes, ornamental pepper plants must be compact and well branched. Therefore, a technique such as pinching, manual removal of shoot apices, to overcome apical dominance and encourage lateral branching is a commercial recommendation in ornamental plant production (Meijon et al., 2009) including pepper (Larson, 1980; Nau, 1989; Vasudevan et al., 2008).

Effects of pinching in terms of significant reduction in plant height, delayed flowering, and increased number of flowering stems have been reported in many commercial flower crops (Debra and Lewis, 1986;

Department of Landscape Architecture, Faculty of Agriculture, University of Akdeniz, Antalya, Turkey

This study was funded by Akdeniz University.

We thank Dr. Anne Frary for critical review of the manuscript.

${ }^{1}$ Corresponding author. E-mail: songulmutlu@akdeniz. edu.tr.
Dorajeerao and Mokashi, 2012; Kumar and Singh, 2003; Malleshappa, 1984). However, information as to any effects of pinching alone on growth and fruiting characteristics of ornamental pepper is limited (Mousa, 2012). Pinching is a very laborintensive process and the need for pinching is one drawback of growing ornamental pepper (Ball, 1985; Hammer, 1980). The use of PGRs for height control offers the opportunity of reducing labor costs (Meijon et al., 2009). Traditional tall cultivars with well-displayed fruit may also be adapted to new commercial demands through the application of PGRs (Basra, 2000; Halmann, 1990). The majority of PGRs used in ornamental plant culture are inhibitors of gibberellin (GA) biosynthesis (Basra, 2000). Triazoles, represented by $\mathrm{PB}$ and uniconazole, are among the PGRs with this mode of action. Paclobutrazol has been reported to be effective in controlling vegetative growth, promoting compactness and flower bud initiation, and is used extensively in the production of many ornamental crops (Davis et al., 1988; Gent 2004; Jiao et al., 1986; Larson, 1985), with varying degrees of success in ornamental pepper (Grossi et al., 2005; Whipker et al., 2000). However, information on the effects of $\mathrm{PB}$ on growth and fruiting characteristics with or without pinching treatments are limited.

The main objective of this work was to understand the influence of $\mathrm{PB}$ with and without pinching on the growth and fruit characteristics of a tall ornamental pepper line. The effectiveness of the foliar application of $\mathrm{PB}$ at different doses on the pinched and nonpinched ornamental pepper growth was evaluated in relation to commercial acceptability represented by both plant growth and fruit set.

\section{Materials and methods}

'M402' is a tall ornamental pepper line (Bircan Seed Co., Antalya, Turkey). The unique variegated foliage color with hues of green to purple and nonpungent attractive fruit of this line make it suitable for ornamental applications. Seeds were sown on 13 Feb. 2013 in bedding plant flats (72-cell size, $82 \mathrm{~mL}$ volume) containing a mixture of peat, perlite, and vermiculite (6:2:1 by volume) and placed under intermittent mist until emergence. The seedlings were kept in trays until first true leaves were fully expanded, fertilized at $75 \mathrm{mg} \cdot \mathrm{L}^{-1}$ nitrogen using $20 \mathrm{~N}-4.4 \mathrm{P}-$ $16.6 \mathrm{~K}$, and then transplanted into $15-$ $\mathrm{cm}$-diameter (2.7-L volume) plastic pots filled with peat, perlite, and vermiculite $(3: 2: 1)$ on 13 Mar. 2013. Plants were grown in a greenhouse at a temperature of $28 / 20 \pm 4{ }^{\circ} \mathrm{C}$ (day/ night) with monthly means of 12.1 , 14.7 , and $17.2 \mathrm{~mol} \cdot \mathrm{m}^{-2} \cdot \mathrm{d}^{-1}$ daily light integral in March, April, and May at Akdeniz University, Antalya, Turkey, and were irrigated as needed. All

\begin{tabular}{llll}
\hline $\begin{array}{l}\text { Units } \\
\text { To convert U.S. to SI, } \\
\text { multiply by }\end{array}$ & U.S. unit & SI unit & $\begin{array}{l}\text { To convert SI to U.S., } \\
\text { multiply by }\end{array}$ \\
\hline 29.5735 & $\mathrm{fl} \mathrm{oz}$ & $\mathrm{mL}$ & 0.0338 \\
3.7854 & gal & $\mathrm{L}$ & 0.2642 \\
2.54 & inch $(\mathrm{es})$ & $\mathrm{cm}$ & 0.3937 \\
25.4 & inch $(\mathrm{es})$ & $\mathrm{mm}$ & 0.0394 \\
28.3495 & $\mathrm{oz}$ & $\mathrm{g}$ & 0.0353 \\
1 & $\mathrm{ppm}$ & $\mathrm{mg} \cdot \mathrm{L}^{-1}$ & 1 \\
$\left({ }^{\circ} \mathrm{F}-32\right) \div 1.8$ & ${ }^{\circ} \mathrm{F}$ & ${ }^{\circ} \mathrm{C}$ & $\left({ }^{\circ} \mathrm{C} \times 1.8\right)+32$
\end{tabular}


plants were fertilized twice a week using the same fertilizer at 140 $\mathrm{mg} \cdot \mathrm{L}^{-1} \mathrm{~N}$ until fruit set and then fertilizer concentration was reduced by half.

Half of the plants were pinched to four nodes from bottom, 6 weeks after sowing on 29 Mar. 2013. Plants were treated with PB (Cultar ${ }^{\circledR}$; Syngenta Crop Protection, Basel, Switzerland) as a spray to the foliage 8 weeks after sowing (i.e., 2 weeks after pinching). Concentrations of $\mathrm{PB}$ were $0,5,10$, and $15 \mathrm{ppm}$ and the mean spray volume was $6.7 \mathrm{~mL}$ per pot. The handheld sprayer was calibrated to deliver $6.7 \mathrm{~mL}$ of solution for each eight full depressions of the trigger mechanism. The spray volume was monitored by spraying into a $10-\mathrm{mL}$ erlenmeyer flask before and after $\mathrm{PB}$ application to every five pots. Control plants were sprayed with tap water. The study was ended at 8 weeks after PB application. Treatments were arranged as $2 \times 4$ factorial with two pinching treatments (pinched and nonpinched) and four $\mathrm{PB}$ concentrations in a randomized complete block design with three replications. Each replication contained five pots per treatment, 120 pots in total.

The plant height and diameter, relative leaf chlorophyll content, fruit number and diameter, and plant dry weight were collected. The plant height was measured weekly beginning 2 weeks after $\mathrm{PB}$ application from the bottom of the pot to the top of the plant, and pot height was subtracted from the total measurement. Canopy diameter was measured weekly beginning at 4 weeks after PB application across the top of the plant using the widest diameter and the two perpendicular measurements were averaged for each plant. To assess aesthetic value, $H / D$ was calculated using plant height and average diameter according to Meijon et al. (2009). Relative leaf chlorophyll content was measured weekly beginning 2 weeks after PB application using a handheld chlorophyll meter (SPAD-502; Spectrum Technologies, Plainfield, IL). The chlorophyll meter provided rapid and nondestructive measurements that correlate well to actual chlorophyll content of leaf (Azia and Stewart, 2001; Richardson et al., 2002). SPAD measurements were taken weekly from the center of three youngest fully expanded leaves of each plant. The fruit was counted on each plant weekly from 4 to 8 weeks after PB application. Fruit diameter was determined on three randomly selected mature fruit on each pot using digital calipers at 8 weeks after $\mathrm{PB}$ application. Plants were harvested from soil surface 8 weeks after $\mathrm{PB}$ application and oven dried at $70{ }^{\circ} \mathrm{C}$ for $72 \mathrm{~h}$ and dry weights were recorded. For the presentation of results regarding growth suppression and fruit yield, the equation used was percent change $=\left[\left(\right.\right.$ response $_{\mathrm{x}}-$ response $\left._{0}\right) /$ $\left(\right.$ response $\left.\left._{0}\right)\right] \times 100$. In this equation, response $_{0}$ denotes control plants, which are nonpinched and received no PB treatment, and response ${ }_{\mathrm{x}}$ denotes the treatments. Analysis of variance was used in data analysis (SAS version 9.0; SAS Institute, Cary, NC). Means were separated using Fisher's protected least significant difference procedure when the $\mathrm{F}$ test indicated significance at $P<0.05$. Data for plant height and diameter, SPAD chlorophyll value, dry weight difference as a function of $\mathrm{PB}$ rate, and fruit number as a function of time were fitted to cubic polynomial models using SPSS (version 17; IBM Corp., Armonk, NY).

\section{Results and discussion}

There were no significant interactions between pinching and $\mathrm{PB}$ rates at most of the evaluation dates, except plant height. However, the main effects were highly significant for the canopy diameter, $\mathrm{H} / \mathrm{D}$ ratio, SPAD chlorophyll value, fruit number and diameter, and dry weight (Tables 1-4). The relationship between $\mathrm{PB}$ and plant height and diameter, SPAD chlorophyll value, dry weight, and fruit number was best explained by a third-order polynomial $\left[r^{2}=0.83-0.99, \mathrm{n}=120\right.$ (Fig. 1A-E)].

Height control is important for ornamental plants to improve commercial quality and adaptability to shipping and transplanting operations

Table 1. Means, percent reduction, and analysis of variance for plant height and height/diameter (H/D) ratio of 'M402' ornamental pepper as influenced by pinching $(\mathrm{P})$ and paclobutrazol $(\mathrm{PB})$ treatments.

\begin{tabular}{|c|c|c|c|c|c|c|c|c|c|c|}
\hline \multicolumn{2}{|c|}{ Treatments } & \multicolumn{9}{|c|}{ Time after PB application (weeks) } \\
\hline \multirow[b]{2}{*}{ Pinching } & \multirow{2}{*}{$\begin{array}{l}\text { PB rate } \\
(\mathrm{ppm})^{\mathrm{z}}\end{array}$} & \multicolumn{2}{|r|}{2} & \multicolumn{2}{|r|}{4} & \multicolumn{2}{|c|}{6} & \multicolumn{2}{|r|}{8} & \multirow{2}{*}{$\frac{8}{\mathrm{H} / \mathrm{D} \text { (ratio) }}$} \\
\hline & & $\mathrm{Ht}(\mathrm{cm})^{y}$ & Change (\%) & $\mathrm{Ht}(\mathrm{cm})$ & Change (\%) & Ht (cm) & Change (\%) & $\mathrm{Ht}(\mathrm{cm})$ & Change (\%) & \\
\hline & 5 & 22.0 & -55 & 22.8 & -61 & 23.5 & -61 & 24.2 & -61 & 1.1 \\
\hline & 10 & 20.6 & -58 & 21.2 & -64 & 21.6 & -64 & 22.3 & -64 & 1.0 \\
\hline & 15 & 20.2 & -59 & 20.6 & -65 & 21.1 & -65 & 21.7 & -65 & 1.0 \\
\hline & 10 & 24.8 & -49 & 26.0 & -56 & 27.4 & -55 & 29.2 & -53 & 1.3 \\
\hline & 15 & 24.5 & -50 & 25.4 & -57 & 26.7 & -56 & 28.0 & -54 & 1.2 \\
\hline $\operatorname{LSD}(0.05)^{y}$ & & 1.6 & & 2.0 & & 2.0 & & 1.9 & & 0.1 \\
\hline \multicolumn{11}{|l|}{ Source ${ }^{x}$} \\
\hline $\mathrm{P}$ & & $* * *$ & & $* * *$ & & $* * *$ & & $* * *$ & & $* * *$ \\
\hline
\end{tabular}

${ }^{2} 1 \mathrm{ppm}=1 \mathrm{mg} \cdot \mathrm{L}^{-1}, \mathrm{l} \mathrm{cm}=0.3937$ inch

'Least significant difference values indicate significant means separation at $P=0.05$.

${ }^{\mathrm{N}} \mathrm{NS},{ }^{*},{ }^{* *},{ }^{* *}$ Nonsignificant or significant at $P<0.05,0.01$, or 0.001 , respectively. 


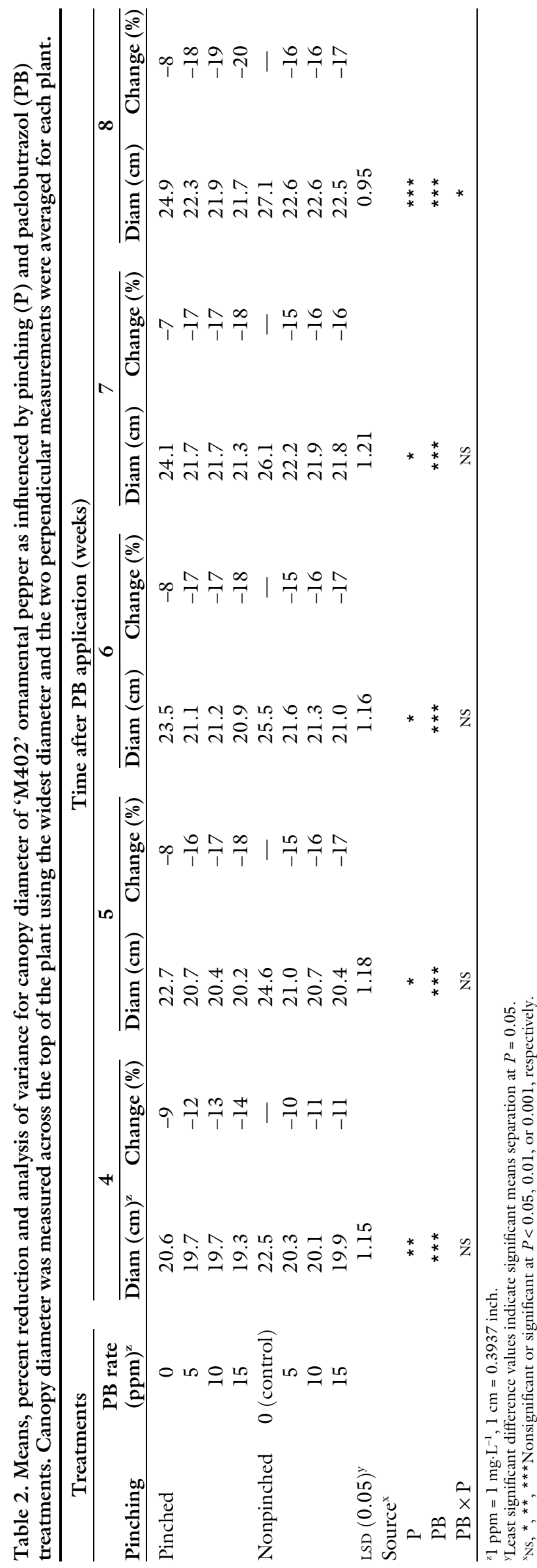

(Agehara and Leskovar, 2014). Plant height varied with pinching and $\mathrm{PB}$ treatments (Table 1 ). Up to $25 \%$ reduction in plant height was achieved with pinching alone. Several studies also reported that apical bud pinching caused significant reduction in plant height of many ornamental plants (Dorajeerao and Mokashi, 2012; Jhon and Paul, 1995; Kumar and Singh, 2002; Malleshappa, 1984). The interaction revealed that $\mathrm{PB}$ rates of 5,10 , and $15 \mathrm{ppm}$ produced similar suppression on nonpinched plants, whereas the $15 \mathrm{ppm} \mathrm{PB}$ yielded a greater suppression than $5 \mathrm{ppm}$ on the pinched plants $(21.6$ vs. $24.2 \mathrm{~cm}$ ) through the 8 -week period. The results indicate that the difference in growth suppression rates between 5 vs. 10 and 15 ppm PB does not justify the use of higher doses. Suppression in plant height by PB ranged from $55 \%$ to $65 \%$ and $46 \%$ to $57 \%$ for pinched and nonpinched plants, respectively (Table 1; Figs. $1 \mathrm{~A}$ and 2). Growth suppression by PB was reported in earlier studies on various plant species (Berova and Zlatev, 2000; Larcher et al., 2011; Maloupa et al., 2000; Wilkinson and Richards, 1987), including pepper (Aloni and Pashkar, 1987; Grossi et al., 2005; Whipker et al., 2000). Grossi et al. (2005) also reported similar growth suppression when PB applied on to nonpinched pepper plants. However, the degree of height control by $\mathrm{PB}$ achieved in our study was higher than that of Whipker et al. (2000). Another triazole-type PGR, uniconazole, reduced the pepper plant height linearly as dose-dependent manner and as much as $50 \%$ with 15 ppm (Starman, 1993). The effectiveness of the PGR may vary depending on the cultivar, plant age and health, nutritional status, environmental conditions, and method of application or timing (Basra, 2000; Halmann, 1990; Smit et al., 2005). Elongations during the 6 -week period were $21 \%$ for nonpinched and $25 \%$ for pinched control plants. Relatively little elongation occurred between weeks 2 and 8 after $\mathrm{PB}$ application where $13 \%$ and $8 \%$ elongations were measured for nonpinched and pinched groups, respectively.

The effects of each PB doses at pinched and nonpinched plants on canopy diameter are presented 
Table 3. Means and analysis of variance for SPAD chlorophyll value and dry weight of 'M402' ornamental pepper as influenced by main effects of pinching $(P)$ and paclobutrazol $(P B)$ treatments. SPAD values are averages of three readings from each plant, the numbers in pinching treatment represent means of 180 , and in PB treatments of 90 readings.

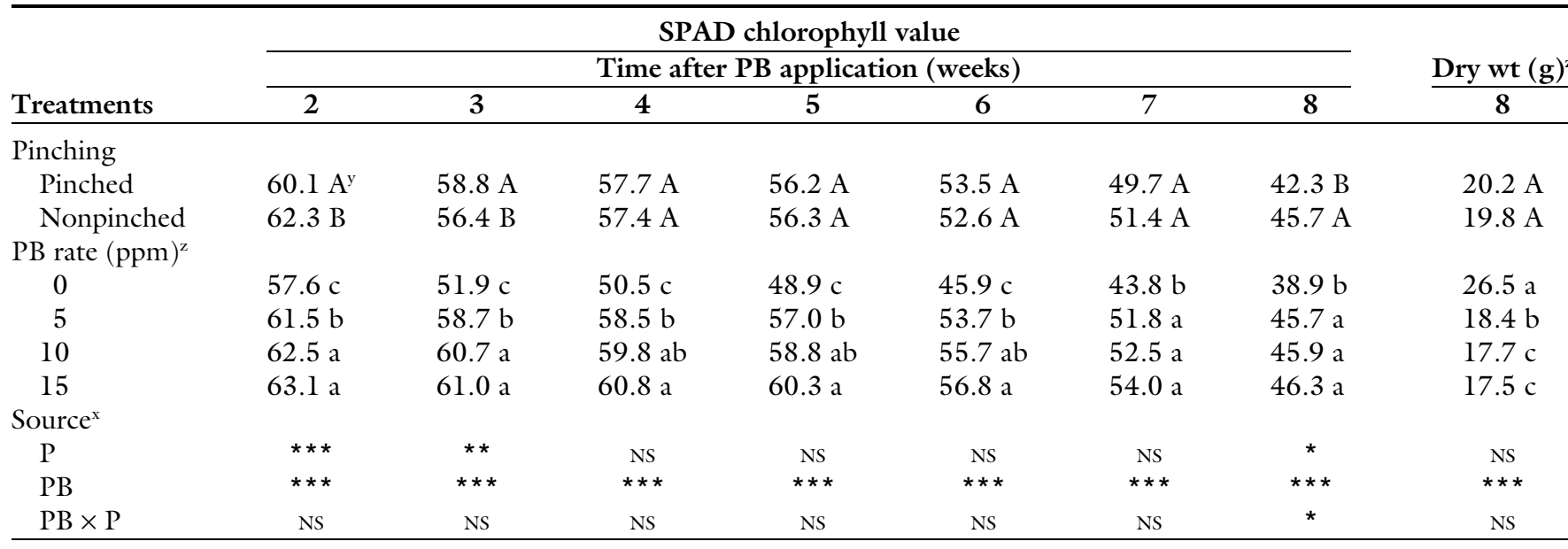

${ }^{\mathrm{z}} 1 \mathrm{~g}=0.0353 \mathrm{oz}, 1 \mathrm{ppm}=1 \mathrm{mg} \cdot \mathrm{L}^{-1}$

Values in the same column that are followed by same letter do not differ significantly according to least significant difference $(P=0.05)$.

${ }^{\mathrm{N}} \mathrm{NS},{ }^{*},{ }^{* *},{ }^{* *}$ Nonsignificant or significant at $P<0.05,0.01$, or 0.001 , respectively.

separately in Table 2. The pinching without $\mathrm{PB}$ application reduced the plant diameter $8 \%$ throughout the evaluation dates. This is the first study reporting the effect of pinching to canopy diameter relative to nonpinched control group in pepper. When 15 ppm PB applied to nonpinched and pinched plants, reduction reached up to $17 \%$ and $20 \%$ 8 weeks after $\mathrm{PB}$ application, respectively. On the pinched pepper plants, Whipker et al. (2000) reported a $13 \%$ reduction in canopy diameter with $\mathrm{PB}$ and Starman (1993) reported a 33\% reduction with uniconazole treatments. Modification of plant architecture by means of pinching and $\mathrm{PB}$ was shown in several ornamentals, but little information is available as to any effects on $\mathrm{H} / \mathrm{D}$ ratio or compactness of ornamental pepper. Maintaining height proportional to the container would improve quality. Although in ornamental plants, it is a difficult aspect to define, an $\mathrm{H} / \mathrm{D}$ ratio around one yielded compact plants with high commercial quality on highly branched azalea [Rhododendron sp. (Bird and Conner, 1999)]. The results demonstrated that pinching alone significantly increased compactness of pepper plants by $17 \%$, reducing the $\mathrm{H} / \mathrm{D}$ ratio from 2.3 to 1.9 (Table 1). The enhanced compactness obtained by pinching may not be sufficient for commercial potted ornamental pepper. But it may be acceptable as bedding plants in landscape settings. The PB applications to pinched and nonpinched plants reduced the $H / D$ ratios down to a range of 1.0 to 1.3 , pointing to a more compact plant type for potted ornamental pepper while control plants had leggy appearance. The pinching and $\mathrm{PB}$ ratios should be tested for each pepper cultivar considering market needs and demands.

The SPAD chlorophyll value was similar between pinched and nonpinched plants while $\mathrm{PB}$ treatment increased it between $7 \%$ and $24 \%$ throughout the 8-week period (Table 3; Fig. 1D). The relative chlorophyll content, relative to the untreated control, was $24 \%$ greater at 6 weeks after PB application. The 15 ppm PB rate enhanced the SPAD chlorophyll value better than 5 ppm until 6 weeks posttreatment and thereafter $\mathrm{PB}$ doses yielded similar results. Increase in relative chlorophyll content with PB measured in this study may be attributed to more densely packed chloroplasts per unit leaf area as a result of reduced leaf elongation and/ or enhanced chlorophyll biosynthesis (Davis et al., 1988; Khalil, 1995). The higher chlorophyll content in PBtreated pepper leaves may also be related to the influence of $\mathrm{PB}$ on endogenous cytokinin level. Triazoles have been proposed to stimulate $\mathrm{cy}^{-}$ tokinin synthesis that enhances chloroplast differentiation, chlorophyll biosynthesis, and prevents chlorophyll degradation (Fletcher et al., $2000)$. Increased cytokinin contents were reported after the application of
GA biosynthesis inhibitors (Grossman, 1992; Sebastian et al., 2002). Enhanced chlorophyll synthesis in pepper, carnation (Dianthus caryophyllus), madagascar periwinkle (Catharanthus roseus), and tomato (Solanum lycopersicum) were reported (Aloni and Pashkar, 1987; Berova and Zlatev, 2000; Grossi et al., 2005; Jaleel et al., 2007; Sebastian et al., 2002). Phytotoxicity was not observed in the present study. Grossi et al. (2005) did not observe phytotoxicity with 6 ppm PB canopy spray. However, 9- and 18-ppm PB drenches caused chlorosis in ornamental pepper (Grossi et al., 2005). Because soil or stem applications of triazoles are more effective in retarding growth than foliar application (Davis et al., 1988), phytotoxicity might be caused by extended exposure to and a higher uptake of PB by plants.

The pinching did not affect plant dry weight while $\mathrm{PB}$ treatment reduced it up to $34 \%$ (Table 3 ). Increasing $\mathrm{PB}$ rates decreased the plant dry weight and fit cubic polynomial models $\left[r^{2}=0.98-0.99\right.$ (Fig. 1C)]. However, Grossi et al. (2005) reported a dose-dependent linear reduction up to $52 \%$ with 6.0 ppm PB. Reduction in plant dry weight with PB was also reported for other ornamental species (Banon et al., 2002; Hammid and Williams, 1997).

In addition to growth habit and foliar characteristics, ornamental peppers have been primarily developed based on unique fruit characteristics (Bosland and Votava, 2000; Stommel 


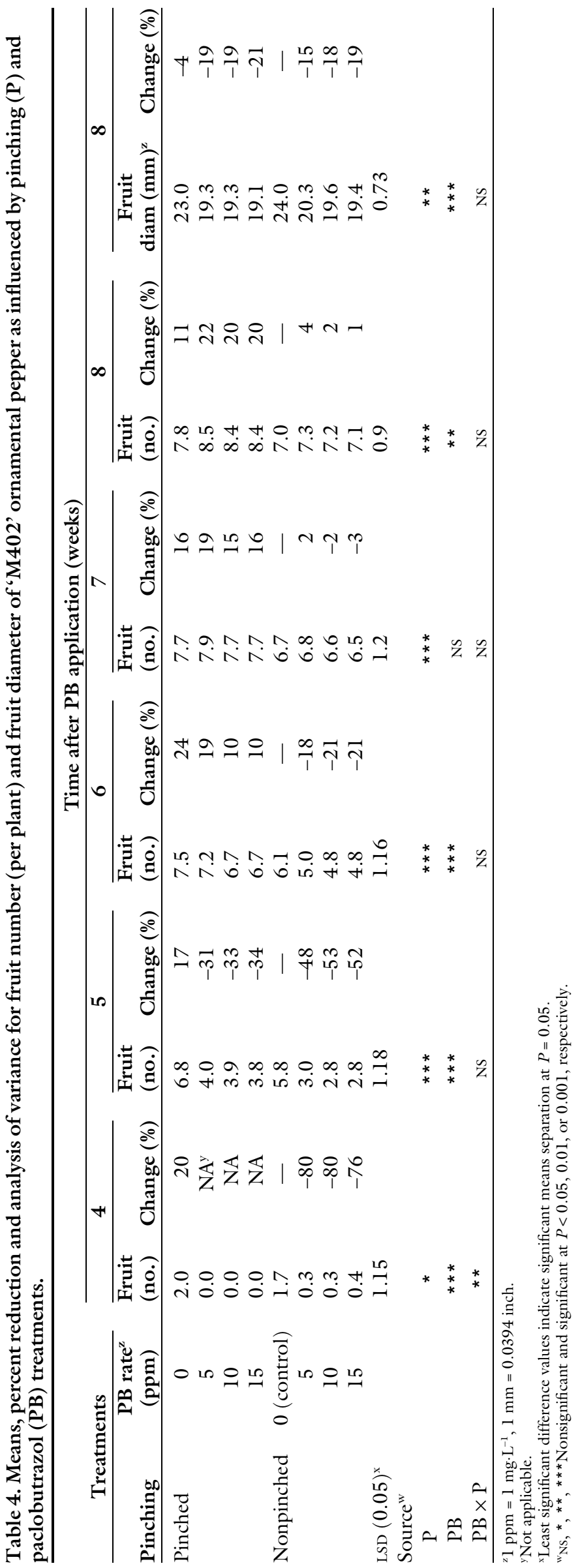

and Griesbach, 2008). Pinching delayed flowering and increased number of flowering stems in ornamental plants (Basavaraj, 1984; Malleshappa, 1984; Maloupa et al., 2000; Pathania et al., 2000; Thakur et al., 2006; Ubukata, 1999). Pinching alone increased the fruit set from 6.1 to 7.5 fruit/plant, a 24\% increase 6 weeks after PB application (Table 4). However, $\mathrm{PB}$ application delayed the fruit set for 2 to 3 weeks on pinched and nonpinched plants, respectively (Table 4). Then, PB treatment enhanced the fruit set from 7.8 to 8.5 and from 7.0 to 7.3 in pinched and nonpinched plants, respectively, 8 weeks posttreatment. Enhancement of fruit yield by $\mathrm{PB}$ was more significant among pinched plants with no significant difference between PB doses (Fig. lE). Over time, change in fruit number of pinched and nonpinched plants with or without $\mathrm{PB}$ treatments fit cubic polynomial models $\left[r^{2}=0.98-\right.$ 0.99 (Fig. 1E)]. Enhanced fruit yield due to pinching can be attributed to increased number of branches per plant (Malleshappa, 1984). Pinching alone decreased fruit diameter slightly while PB reduced it by $15 \%$ to $21 \%$ (Table 4). Contrary to our results, pinching applied at 8 weeks after sowing did not influence fruit yield and fruit size of the pepper 'NM 6-4' (Mousa, 2012). Time of pinching might be the reason for the conflicting results as shown in chrysanthemum (Dendranthema grandiflorum) with significant differences in number of flowers per plant (Singh and Baboo, 2003). Reduction in fruit size by pinching and $\mathrm{PB}$ might be the result of competition between increased fruit. Similar to our findings in pepper, increasing $\mathrm{PB}$ concentrations decreased fruit diameter but increased the number of fruit in ornamental tomato (de Moraes et al., 2005), where the number of cluster per plant and the number of cluster with fruit also increased linearly by increasing drench PB concentrations. Increased fruit yield may be attributed to the allocation of more carbohydrates to the fruit, probably by redistributing assimilates and directing the majority of assimilates toward reproductive growth (Arzani and Roosta, 2004; Katz et al., 2003) or to the enhanced cytokinin content promoted by $\mathrm{PB}$ (Rademacher, 2000). Involvement of cytokinins in both floral stimulus and 

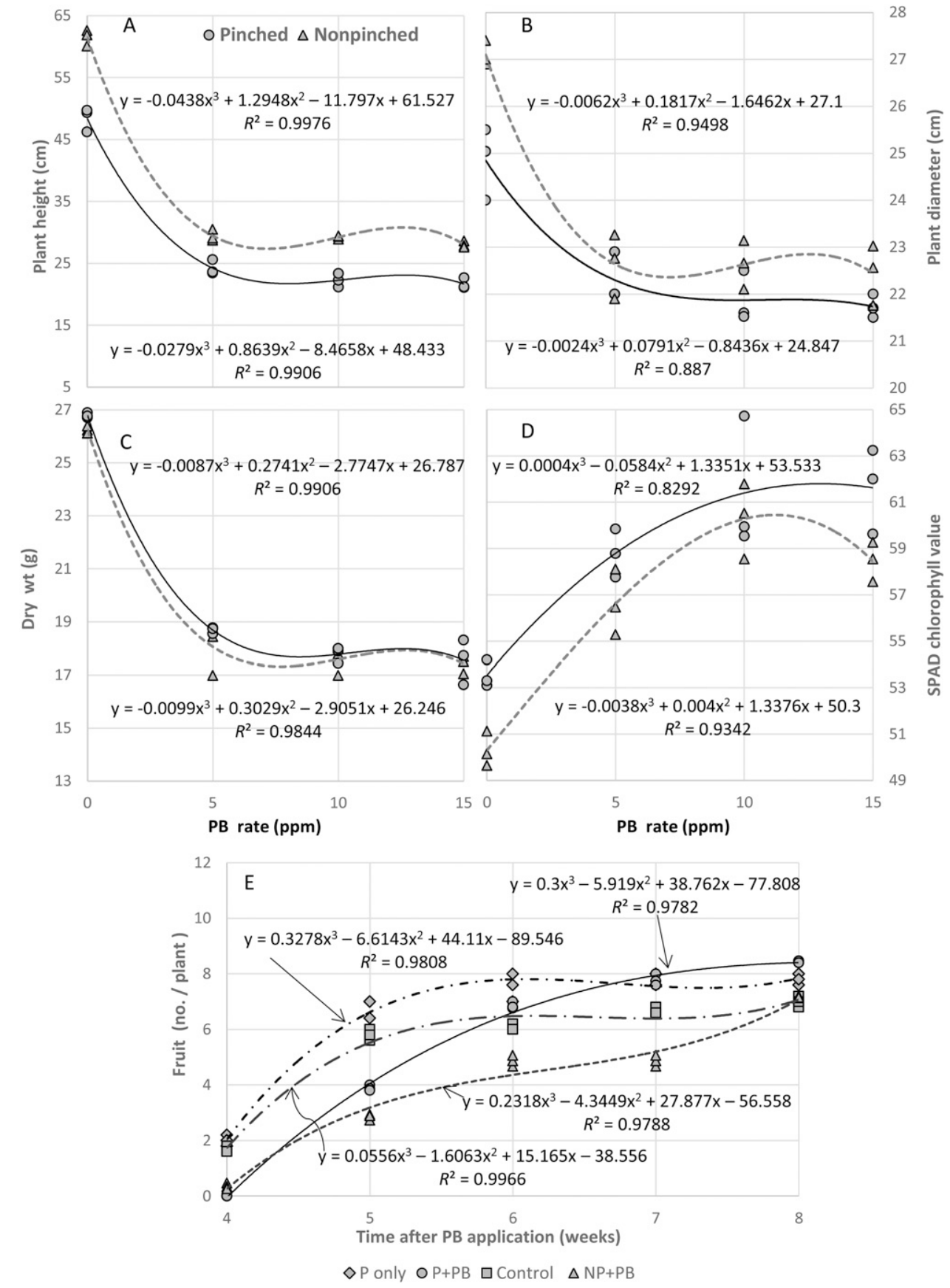

Fig. 1. Change in plant height (A), plant diameter (B), and dry weight (C) 8 weeks after treatment (WAT); SPAD chlorophyll values (D) three WAT in response to paclobutrozol (PB) rates. 'M402' ornamental pepper plants received a foliar spray of 0 , 5 , 10 , or $15 \mathrm{mg} \cdot \mathrm{L}^{-1}$ PB 8 weeks after sowing ( 2 weeks after pinching). Each point represents mean of five replicates. The solid and broken lines represent regression lines generated for the entire population data using cubic polynomial models for pinched (P) $(\bullet)$ and nonpinched $(\mathrm{NP})$ plants $(\Delta)$, respectively. Increase in fruit number over time $(\mathrm{E})$ of $\mathrm{P}$ only $(\diamond), \mathbf{P}+\mathrm{PB}(\bullet)$, control $(\square)$, and NP + PB $(\Delta)$ plants; $1 \mathrm{~cm}=0.3937$ inch, $1 \mathrm{~g}=0.0353 \mathrm{oz}, 1 \mathrm{ppm}=1 \mathrm{mg} \cdot \mathrm{L}^{-1}$.

development has been reported (Chang et al., 1999; Corbesier et al., 2003; Dello Loio et al., 2008; Dewitte et al., 1999; Meijon et al., 2010).

\section{Conclusions}

Ornamental peppers have become a profitable crop for pot plant and transplant production and may provide added value for greenhouse growers. The plants of 'M402' ornamental pepper used in this study grew out of proportion to their commercially accepted pots unless they were treated with $\mathrm{PB}$. Pinching alone recognizably increased branching and fruit number, but failed to provide marketable size potted ornamental pepper (Sachs et al., 1976). Although, $\mathrm{PB}$ substituted pinching at 5-ppm concentrations for growth suppression and produced compact ornamental pepper plants that were proportional to their pot size, pinching seemed necessary for enhanced branching. Paclobutrazol may offer an economic advantage for commercial greenhouse operators in producing small, commercially acceptable, compact plants that can be spaced 


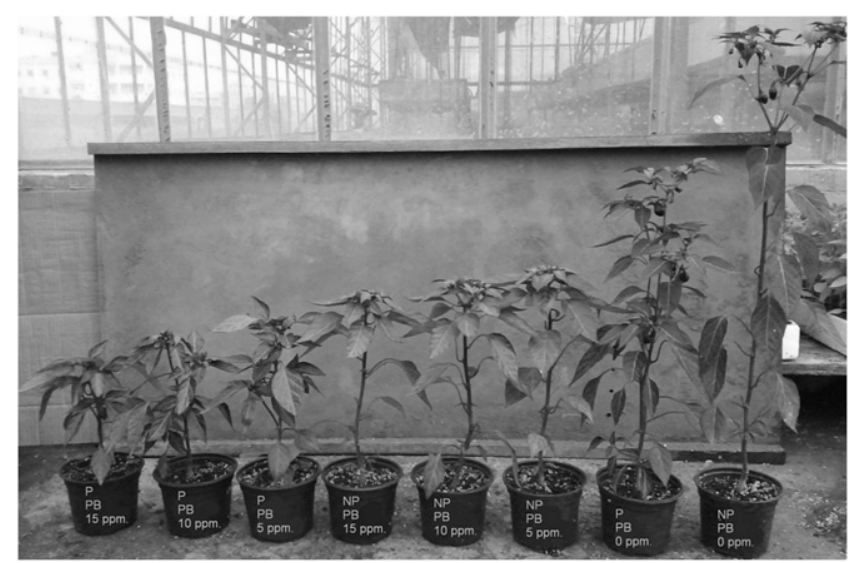

Fig. 2. Image of 'M402' ornamental peppers 4 weeks after paclobutrazol (PB) treatments applied at 5,10 , or $15 \mathrm{ppm}$ with $(\mathrm{P})$ and without $(\mathrm{NP})$ pinching; $1 \mathrm{ppm}=$ $1 \mathrm{mg} \cdot \mathrm{L}^{-1}$.

closer. The absence of phytotoxicity and enhanced fruit yield on pinched plants were advantages of $\mathrm{PB}$. Hence, for ornamental peppers, 5 ppm PB applied to pinched plants is strongly recommended to improve production.

\section{Literature cited}

Agehara, S. and D.I. Leskovar. 2014. Age dependent effectiveness of exogenous abscisic acid in height control of bell pepper and jalapeno transplants. Sci. Hort. 175:193-200.

Aloni, B. and T. Pashkar. 1987. Antagonistic effects of paclobutrazol and gibberellic acid on growth and some biochemical characteristics of pepper (Capsicum annuum) transplants. Sci. Hort. 33:167-177.

Arzani, K. and H.R. Roosta. 2004. Effects of paclobutrazol on vegetative and reproductive growth and leaf mineral content of mature apricot (Prunus armeniaca L.) trees. J. Agr. Sci. Technol. 6:43-55.

Azia, F. and K.A. Stewart. 2001. Relationship between extractable chlorophyll and SPAD values in muskmelon leaves. J. Plant Nutr. 24:961-966.

Ball, V. 1985. Ornamental pepper and christmas cherry, p. 601-603. In: V. Ball (ed.). Ball red book. Reston Publ., Reston, VA.

Basavaraj, S.H. 1984. Influence of pinching and growth retardants on growth and development of marigold cv. African Giant. MSc Thesis, Univ. Agr. Sci., Dharwad, India.

Basra, A.S. 2000. Plant growth regulators in agriculture and horticulture: Their role and commercial uses. Haworth Press, Binghamton, NY

Banon, S., A. Gonzalez, E.A. Cano, J.A. Franco, and J.A. Fernandez. 2002. Growth, development and colour response of potted Dianthus caryophyllus cv. Mondiraan to paclobutrazol treatment. Sci. Hort. 94:371-377.

Berova, M. and Z. Zlatev. 2000. Physiological response and yield of paclobutrazol treated tomato plants (Lycopersicon esculentum Mill.). Plant Growth Regulat. $30: 117-123$

Bird, R.E. and J.L. Conner. 1999. Container grown azalea response to sumagic sprays. Proc. Southern Nursery Assn. Res. Conf. 44:274-276.

Bosland, P.W. and E. Votava. 2000. Peppers: Vegetable and spice capsicums. CAB Intl., Wallingford, UK.

Chang, S.T., W.S. Chen, C.Y. Hsu, H.C. Yu, B.S. Du, and K.L. Hung. 1999. Changes in cytokinin activities before, during and after floral initiation in Polianthes tuberosa. Plant Physiol. Biochem. 37:679-684.

Corbesier, L., E. Prinsen, A. Jacqmard, P. Lejeune, H. Van Onckelen, C. P'erilleux, and G. Bernier. 2003. Cytokinin levels in leaves, leaf exudate and shoot apical meristem of Arabidopsis thaliana during floral transition. J. Expt. Bot. 54:2511-2517.

Davis, T.D., G.L. Steffans, and N. Sankhla. 1988. Triazole plant growth regulators. Hort. Rev. 10:63-105.

Debra, R.B. and A.J. Lewis. 1986. Preplant application of growth retardants to pinched and unpinched chrysanthemum cuttings. Sci. Hort. 28:159-164.

Dello Loio, R., F.S. Linhares, and S. Sabatini. 2008. Emerging role of cytokinin as a regulator of cellular differentiation. Curr. Opin. Plant Biol. 11:23-27.

de Moraes, P.J., J.A. Saraiva Grossi, S. de Araújo Tinoco, D.J. Henriques da Silva, P.R. Cecon, and J.G. Barbosa. 2005. Ornamental tomato growth and fruiting response to paclobutrazol. Acta Hort. 683:327-332.

Dewitte, W., A. Chiappetta, A. Azmi, E. Witters, M. Strnad, J. Rembur, M. Noin, D. Chriqui, and H. Van Onckelen. 1999. Dynamics of cytokinins in apical shoot meristems of a day-neutral tobacco during floral transition and flower formation. Plant Physiol. 119:111-121.

Dorajeerao, A.V.D. and A.N. Mokashi. 2012. Growth analysis as influenced by pinching time in garland chrysanthemum (Chrysanthemum coronarium L.). Global J. Bio-Sci. Biotechnol. 1:242-247.

Fletcher, R.A., A. Gilley, N. Sankhla, and T.D. Davis. 2000. Triazoles as plant growth regulators and stress protectants. Hort. Rev. 24:55-138.

Gent, M.P.N. 2004. Efficacy and persistence of paclobutrazol applied to rooted cuttings of rhododendron before transplant. HortScience 39:105-109.

Grossman, K. 1992. Plant growth retardants: Their mode of action and benefit for physiological research, p. 788-797. In: C.M. Karssen, L.C. Van Loon, and D. Vreugdenhil (eds.). Progress in plant growth regulations. Kluwer Academic, Dordrecht, The Netherlands.

Grossi, J.A.S., P.J. De Moraes, S. De Araujo Tinoca, J.G. Barbosa, F.L. Finger, and P.R. Cecon. 2005. Effects of paclobutrazol on growth and fruiting characteristics of 'Pitanga' ornamental pepper. Acta Hort. 683:333-336.

Halmann, M. 1990. Synthetic plant growth regulators. Adv. Agron. 43:47-105.

Hammer, P.A. 1980. Other flowering pot plants, p. 442-445. In: R.A. Larson (ed.). Introduction to floriculture. Academic Press, New York, NY.

Hammid, M.M. and R.R. Williams. 1997. Effect of different types and concentrations of plant growth retardants on Sturt's desert pea (Swainsona formmosa). Sci. Hort. 71:79-85.

Jaleel, C.A., P. Manivannan, B. Sankar, A. Kishorekumar, S. Sankari, and R. Panneerselvam. 2007. Paclobutrazol enhances photosynthesis and ajmalicine production in Catharanthus roseus. Process Biochem. 42:1566-1570.

Jhon, A.Q. and T.M. Paul. 1995. Influence of spacing and pinching treatments on growth and flower production in chrysanthemum (Chrysanthemum morifolium Ramat) cv. Flirt. Prog. Hort. 27:57-61.

Jiao, J., M.J. Tsujita, and D.P. Murr. 1986. Effects of paclobutrazol and A-rest on growth, flowering, leaf carbohydrate and leaf senescence in 'Nellie White' 
easter lily (Lilium longiflorum Thunb.). Sci. Hort. 30:135-141.

Katz, E., O. Ziv, R. Venkatachalam, E. Shlomo, A.H. Halevy, and D. Weiss. 2003. Promotion of Globularia sacorphylla flowering by uniconazol, an inhibitor of gibberellin biosynthesis. Sci. Hort. 98:423-431.

Khalil, I.A. 1995. Chlorophyll and carotenoid contents in cereals as affected by growth retardants of triazole series. Cereal Res. Commun. 23:183-189.

Kumar, R. and K. Singh. 2002. Effect of growth regulator and shoot tip pinching on carnation. J. Ornamental Hort. 6:134136.

Kumar, R. and K. Singh. 2003. Regulating growth and flowering in carnation through planting date, photo period, gibberellic acid and pinching treatments. Haryana Hort. Sci. 32:69-72.

Larcher, F., A. Berruti, P. Gullino, and V. Scariot. 2011. Reducing peat and growth regulators input in camellia pot cultivation. Hort. Sci. (Prague) 38:35-42.

Larson, R.A. 1980. Introduction to floriculture. Academic Press, New York, NY.

Larson, R.A. 1985. Growth regulators in floriculture. Hort. Rev. 7:399-481.

Malleshappa, H. 1984. Influence of pinching and CCC on growth and yield of china aster cv. Ostrich Plume. Univ. Agr. Sci., Dharwad, India, MSc Diss.

Maloupa, E., D. Gerasopoulos, A. Marnasidis, and D. Zervaki. 2000. Paclobutrazol and pinching affects visual quality characteristics of potted Vitex agnus-castus plants. Acta Hort. 541:295-298.

Meijon, M., R. Rodriguez, M.J. Canal, and I. Feito. 2009. Improvement of compactness and floral quality in azalea by means of application of plant growth regulators. Sci. Hort. 119:169-176.

Meijon, M., M.J. Canal, H. Fernandez, A. Rodriguez, B. Fernandez, R. Rodriguez, and I. Feito. 2010. Hormonal profile in vegetative and floral bud of azalea: Levels of polyamines, gibberellins, and cytokinins. J. Plant Growth Regul. 30:74-82.

Mousa, A. 2012. Effect of hand pinching, dikegulac-sodium, and gibberellic acid on chile pepper (Capsicum annuum). Mississippi State Univ. MSc Diss.

Nau, J. 1989. Ball culture guide. The encyclopedia of seed germination. Ball Seed Co., West Chicago, IL.

Pathania, N.S., O.P. Sehgal, and Y.C. Gupta. 2000. Pinching for flower regulation in Sim carnation. J. Ornamental Hort. 3:114-117.

Rademacher, W. 2000. Growth retardants: Effects on gibberellin biosynthesis and other metabolic pathways. Annu. Rev. Plant Physiol. Plant Mol. Biol. 51:501-531.

Richardson, A.D., S.P. Duigan, and G.P. Berlyn. 2002. An evaluation of noninvasive methods to estimate foliar chlorophyll content. New Phytol. 153:185194.

Rubatzky, V.E. and M. Yamaguchi. 1997. World vegetables: Principles, production and nutritive values. Chapman and Hall, New York, NY.

Sachs, R.M., A.M. Kofranek, and W.P. Hackett. 1976. Evaluating new pot plant species. Florist Rev. 159:35-36.

Sebastian, B., G. Alberto, A.C. Emilio, A.F. Jose, and A.F. Juan. 2002. Growth development and color response of potted Dianthus caryophyllus to paclobutrazol treatment. Sci. Hort. 1767:1-7.

Singh, M.K. and R. Baboo. 2003. Response of $\mathrm{N}, \mathrm{K}$ and pinching levels on growth and flowering in chrysanthemum. J. Ornamental Hort. 6:390-393.

Smit, M., J.J. Meintjes, G. Jacobs, P.J.C. Stassen, and K.I. Theron. 2005. Shoot growth control of pear trees (Pyrus communis
L.) with prohexadione-calcium. Sci. Hort. 106:515-529.

Starman, T.W. 1993. Ornamental pepper growth and fruiting response to unicanozole depends on application time. HortScience 28:917-919.

Stommel, J.R. and P.W. Bosland. 2006. Ornamental pepper, Capsicum annuum, p. 561-599. In: N.O. Anderson (ed.). Flower breeding and genetics: Issues, challenges and opportunities for the 21 st century. Springer, Dordrecht, The Netherlands.

Stommel, J.R. and R.J. Griesbach. 2008. Capsicum annuum L. midnight creeper and solar eclipse. HortScience 43:939942.

Thakur, R., A. Sood, P.K. Nagar, S. Pandey, R.C. Sobti, and P.S. Ahuja. 2006. Regulation of growth of Lilium plantlets in liquid medium by application of paclobutrazol or ancymidol, for its amenability in a bioreactor system: Growth parameters. Plant Cell Rpt. 25:382-391.

Ubukata, M. 1999. Evaluation of one-half pinch method of spray carnation cultivation in Hokkaido. Hokkaido Prefectural Agr. Expt. Sta. Res. Bul. 77:39-43.

Vasudevan, S.N., J.S. Sudarshan, and M. B. Kurdikerl. 2008. Influence of pinching of apical bud and chemical sprays on seed yield and quality of fenugreek. Karnataka J. Agr. Sci. 21:26-29.

Whipker, B.E., I. McCall, and J.L. Gibson. 2000. Bonzi has advantages over Sumagic as a growth regulator for ornamental pepper. North Carolina State Univ. Floriculture Res. Rpt. 146:1-4. 20 Feb. 2015. <http://www.ces.ncsu.edu/depts/hort/ floriculture/hrs/Orn\%20Pepper\%20PGR \%20Report.pdf>.

Wilkinson, R.J. and D. Richards. 1987. Effects of paclobutrazol on growth and flowering of Bouvardia humboldtii. HortScience 22:444-445. 